\title{
Crumbs of Comfort: Pregnancy and the Status of 'Worker' under EU Law's Free Movement Provisions
}

\author{
Case C-507/12 Jessy Saint Prix v Secretary of State for Work and Pensions, Judgment of the Court \\ of Justice of the EU, (First Chamber), 19 June 2014
}

\section{INTRODUCTION}

In Jessy Saint Prix v Secretary of State for Work and Pensions ${ }^{1}$ the Court of justice of the EU (CJEU) has ruled that an EU migrant who gives up work or seeking work because of the physical constraints of the late stages of pregnancy and the aftermath of childbirth can retain the status of 'worker'. In order to do so, she must return to work or find another job within a reasonable period after the birth of her child. In determining whether the period that has elapsed between childbirth and starting work again might be regarded as 'reasonable', national courts should take account of all of the specific circumstances of the case as well as national rules on the duration of maternity leave.

The case, which was referred to the CJEU by the UK's Supreme Court, raises a number of important issues concerning EU worker status, equal treatment between men and women and protection against pregnancy discrimination under EU law against the backdrop of the rise of precarious work. Furthermore, its origin as a UK case is of particular interest due to the coalition government's welfare reforms and recent statements regarding plans to curb EU migration and to further restrict welfare benefits to EU migrants.

\section{THE FACTS AND CASE HISTORY}

The claimant, a French national and qualified teacher, arrived in the UK in 2006 and worked for eleven months as a teaching assistant. Having enrolled on a PG Certificate in Education in September 2007, she became pregnant and withdrew from the course in February 2008. Her baby was due in early June 2008. She sought work as a secondary school teacher and registered with an employment agency which, unable to place her in a post commensurate with her qualifications, provided her with a succession of posts in nursery schools. In March 2008 when she was almost six months pregnant, she stopped this work as caring for young children had become too strenuous. Instead she looked for part-time work and, as none was available, she made a claim for income support (IS), a benefit which may be granted to certain categories of people whose income is below a defined threshold. Women who are pregnant or who have recently given birth may be eligible for IS, in particular during the period surrounding childbirth. As she was now 11 weeks away from her expected week of confinement (EWC), Ms Saint Prix's claim for IS was supported by her GP. ${ }^{2}$ For those who do not habitually reside in the UK, eligibility for IS is dependent on the claimant's ability to show that she has acquired the status of 'worker' within the meaning of Directive 2004/38/EC (hereinafter 'the

\footnotetext{
${ }^{1}$ Case C-507/12, judgment of $19^{\text {th }}$ June 2014 , nyr.

${ }^{2} 11$ weeks before the EWC is the earliest point at which the maternity leave period may commence under UK provisions - Maternity and Parental Leave, etc. Regulations 1999, reg. 4(2).
} 
Citizenship Directive' $)^{3}$ which provides EU citizens and their family members with certain qualified free movement rights. On $4^{\text {th }}$ May 2008 Ms Saint Prix's claim was refused on the grounds that she did not have a right to reside because she was no longer working and could not retain the status of worker because she had voluntarily chosen to leave the labour market. Under the relevant UK legislation, ${ }^{4}$ Ms Saint Prix was classified as 'a person from abroad' and was, thus, not deemed to be a worker for the purposes of the Citizenship Directive. Her child was born prematurely and she resumed work on a full-time basis in August 2008, just three months after the birth.

In late 2008 Ms Saint Prix appealed against the decision to refuse her claim for income support and her appeal was originally upheld by the First Tier Tribunal. However, the Secretary of State lodged a subsequent appeal against that decision which was upheld by the Upper Tribunal on 7 May 2010 and confirmed by the Court of Appeal. ${ }^{5}$ The case was heard by the Supreme Court in October 2012 and a request was made for a preliminary ruling by the $\mathrm{CJEU}^{6}$ to consider the following questions:

1. Is the right of residence conferred upon a 'worker' in Article 7 of the Citizenship Directive to be interpreted as applying only to those

i) in an existing employment relationship,

ii) at least in some circumstances) seeking work, or

iii) covered by the extensions in article 7(3), or is the Article to be interpreted as not precluding the recognition of further persons who remain 'workers' for this purpose?

2. i) If the latter, does it extend to a woman who reasonably gives up work, or seeking work, because of the physical constraints of the late stages of pregnancy (and the aftermath of childbirth)?

ii) If so, is she entitled to the benefit of the national law's definition of when it is reasonable for her to do so?

Before exploring the CJEU's ruling in more detail, it is worth noting the wholly precarious position in which migrant women who are unable to claim income support for the eight weeks surrounding the expected date of confinement find themselves under UK law. This was acknowledged by Lady Hale who, in setting out the relevant UK law applicable to pregnant women, noted that a woman who is beyond the date at which she is classified as 'actively seeking work ${ }^{77}$ and, thus eligible for Jobseeker's Allowance but who has not yet passed the two weeks following the birth during which she is statutorily prevented from working, ${ }^{8}$

...without other sources of income (including statutory maternity pay and other social security benefits for which some but not all pregnant women are eligible)...will be left destitute unless income support is available. ${ }^{9}$

\footnotetext{
${ }^{3}$ Directive 2004/38/EC of the European Parliament and of the Council of 29 April 2004 on the right of citizens of the Union and their family members to move and reside freely within the territory of the Member, OJ 2004 L 158, p. 77, and corrigenda OJ 2004 L 229, p. 35, and OJ 2005 L 197, p. 34.

${ }^{4}$ The Social Security (Incapacity for Work) (General) Regulations 1995, regulation 21AA.

${ }^{5}$ Saint-Prix v Secretary of State for Work and Pensions [2011] EWCA Civ 806.

${ }^{6}$ Under Article 45 TFEU.

${ }^{7}$ Specifically 6 weeks before the expected date of confinement.

${ }^{8}$ By virtue of regulation 14 of the Social Security (Incapacity for Work) (General) Regulations 1995.

${ }^{9}$ Judgment of the Supreme Court [2012] UKSC 49, at para 4.
} 
The questions posed by the Court are therefore essential in clarifying the extent of the obligation owed by a host member state to an EU migrant who for reasons related to pregnancy and maternity is temporarily unable to work: a situation that can only apply to women. This goes straight to the heart of the application of the fundamental general principle of equal treatment between men and women which would amount to little more than a meaningless platitude if the Court of Appeal's judgment in the current case were allowed to stand.

\section{THE JUDGMENT OF THE COURT OF JUSTICE OF THE EUROPEAN UNION}

In formulating its responses to the questions referred, the CJEU considered the circumstances in which EU citizens who have previously been employed in the host Member State retain the status of worker, and consequently their eligibility for benefits including IS. Article 7(3) of the Citizens' Directive provides that a person retains the status of worker in certain circumstances, i.e. if they are 'temporarily unable to work as a result of an illness or accident', or 'in recorded involuntary unemployment' and registered as a job-seeker with the relevant employment office (subject to certain further conditions) or undertaking vocational training related to their prior employment. The Directive makes no reference to a temporary inability to work due to the physical constraints of pregnancy and/or the aftermath of childbirth, nor does it state whether the list of circumstances is exhaustive (as argued by the UK Government). The Court, drawing on its earlier jurisprudence in a long line of employment cases, ${ }^{10}$ veered away from applying the 'illness or accident' provision to Ms Saint Prix's case as 'pregnancy must be clearly distinguished from illness, in that pregnancy is not in any way comparable with a pathological condition'. ${ }^{11}$

The Court went on to state that the Citizenship Directive could not in itself limit the scope of the concept of 'worker' which, within the meaning of free movement of persons as provided by Article 45 TFEU, must be interpreted broadly. ${ }^{12}$ Consequently, 'classification as a worker under Article 45 TFEU, and the rights deriving from such status, do not necessarily depend on the actual or continuing existence of an employment relationship'. ${ }^{13}$ Thus, the constraints imposed on a woman's ability to engage in work due to the effects of pregnancy and childbirth do not, in principle, deprive her of the status of 'worker' within the meaning Article 45 TFEU. ${ }^{14}$ Furthermore, her temporary nonavailability on the labour market 'does not mean that she has ceased to belong to that market during that period, provided she returns to work or finds another job within a reasonable period after confinement. ${ }^{15}$ In assessing what would amount to a 'reasonable period' in such circumstances, national courts should take account of the specific circumstances of each case and the applicable national rules on the duration of maternity leave in accordance with Article 8 of the

\footnotetext{
${ }^{10}$ Up to and including C 32/93 Webb v EMO Air Cargo [1994] ECR I-03567.

${ }^{11}$ CJEU judgment in Saint Prix, at 29.

12 lbid at 32 and 33.

${ }^{13}$ Ibid at 37.

${ }^{14} \mathrm{Ibid}$ at 40.

15 Ibid at 41.
} 
Pregnant Workers Directive ${ }^{16}$ which provides for a continuous period of maternity leave of at least 14 weeks long duration, 2 weeks of which must be given compulsorily around the time of the birth.

Finally, the Court agreed with the Commission's submission that an EU migrant who gave up work in the host state due to pregnancy and thus risked losing her status as a worker would be deterred from exercising her right to freedom of movement. ${ }^{17}$ It then went on to consider the special protection guaranteed for women in relation to pregnancy noting that, in the calculation of the five year's continuous residence in the host state which is required for the acquisition of permanent residence, Article 16(3) of the Citizenship Directive allows for a continuous absence of up to 12 months 'for important reasons such as pregnancy and childbirth' ${ }^{18}$ Applying the same reasoning, a temporary absence from the labour market due to pregnancy and childbirth 'cannot, a fortiori, result in that woman losing her status as a worker. ${ }^{19}$

As a consequence of its analysis, the Court held that the answer to the questions referred was,

that Article 45 TFEU must be interpreted as meaning that a woman who gives up work, or seeking work, because of the physical constraints of the late stages of pregnancy and the aftermath of childbirth retains the status of 'worker', within the meaning of that article, provided she returns to work or finds another job within a reasonable period after the birth of her child. ${ }^{20}$

The case will now return to the Supreme Court for its final judgment.

\section{ANALYSIS}

\section{A. INTRODUCTION}

Although welcomed due to its confirmation of the status of migrant women workers who temporarily stop work due to pregnancy, the circumstances surrounding this case and, in some respects the CJEU's judgment itself, throw a spotlight on a particularly inimical corner of EU law which somehow appears to have developed without regard to the fact that a large proportion of the European labour market consists of women of childbearing age. Although the Court's judgment provides some assurance that women migrants who find themselves in the unfortunate circumstances experienced by the claimant will be able to retain 'worker' status, the case confirms the fact that under the EU market order pregnancy and care-giving is commodified and found to be of little or no value. ${ }^{21}$ By focussing exclusively on the impact of the woman's absence on the labour market, the Court avoided confronting what the effect would be on her and/or her child in the event

\footnotetext{
${ }^{16}$ Council Directive 92/85/EEC of 19 October 1992 on the introduction of measures to encourage improvements in the safety and health at work of pregnant workers and workers who have recently given birth or are breastfeeding (tenth individual Directive within the meaning of Article 16(1) of Directive 89/391/EEC), OJ 1992 L 348, p. 1.

${ }^{17}$ CJEU Judgment at 44.

18 Ibid at 45.

19 Ibid at 46.

${ }^{20}$ Ibid at 47.

${ }^{21}$ See N. Busby, A Right to Care: Unpaid Care Work in European Employment Law (OUP, 2011)
} 
that she was unable to return to work within a reasonable period following childbirth, perhaps for a reason related to the health and/or wellbeing of her child or due to a lack of suitable employment. In such circumstances she would, presumably, be subjected to withdrawal of her status as a worker and consequently the denial of any related means of subsistence and, ultimately, the possibility of deportation to her home state. Can this be seen as anything other than the exercise of a punitive measure in what would already be extremely difficult circumstances? The imposition of a pregnancy penalty seems particularly unfair given that its avoidance appears to depend on the claimant's ability to secure employment within what is an increasingly precarious labour market, particularly for those who seek to combine unpaid care for a dependent child with paid employment. That it should be applied in circumstances where an EU migrant simply exercises her right to free movement, which is after all one of the founding principles of EU law, appears to be particularly unjust.

It is worth noting that the relevance of this judgment is limited to a relatively small number of women as those who are already employed at the time that they temporarily cease work on the grounds of pregnancy will be protected from dismissal and will have a secured right to return under the rights conferred by the Pregnant Workers' Directive. ${ }^{22}$ Furthermore, the majority of pregnant migrant workers in the UK will not be reliant on IS due to their eligibility for statutory maternity pay or maternity allowance. However, access to IS (and similar benefits in other Member States) will be of crucial importance to those who do not satisfy the relevant qualifying periods and other eligibility criteria for maternity pay or allowance which, given the increasing insecurity underpinning women's employment in many sectors, are likely to comprise a growing number. Furthermore, that the judgment has application to a relatively small number of women does not of course make it any less important and arguably makes the UK Government's tenacity in fighting the case appear even more questionable.

The circumstances surrounding Saint Prix relate to the gendered nature of the free movement provisions and their incremental interpretation by the Court over many years under which an individual's status depends almost exclusively on her direct market value. In its interpretation of the relevant provisions, the Court has consistently disregarded reproductive labour and associated caregiving as non-economic activities. ${ }^{23}$ Against that backdrop it is hardly surprising that a migrant woman's right to retain worker status following childbirth will depend, not on the state of her health and wellbeing or that of her offspring nor on her financial stability, but on her ability to get back to work as soon as possible. Even the language deployed in this area of EU law (the Court refers to the claimant 'belonging' to the labour market of the host state ${ }^{24}$ ), betrays a lack of consideration of the often harrowing life stories that lie behind the Court's case law. The only reference to the effects of pregnancy and childbirth in the CJEU's judgment arises in relation to their being the cause of an (inconvenient) absence from the labour market - the Court refers to Ms Saint Prix's absence from the labour market on the grounds of pregnancy as an 'interruption of her professional activity'. ${ }^{25}$ Of course this approach is supported by the legislative provision which brought the case before the Court in the first place. The omission of pregnancy as one of the specified grounds provided under

\footnotetext{
${ }^{22}$ Article 10.

${ }^{23}$ Case 44/88 Achterberg-te Riele and others v Sociale Verzekeringsbank [1989] ECR 1963; Case C-31/90 Johnson v Chief Adjudication Officer [1991] ECR I-3723; Case C-325/09 Secretary of State for Work and Pensions v Dias [2010] 1 CMLR 112.

${ }^{24}$ CJEU judgment, para 41.

${ }^{25}$ Ibid, para 39.
} 
Article 7(3) on which an individual requiring a temporary absence from work will be protected from the loss of worker status speaks volumes. The explicitly permitted grounds (illness, accident, involuntary unemployment and vocational training) are likely to have a narrower impact on a smaller number of individuals than the natural state of pregnancy which will affect most women at least once during the life cycle, yet it was the latter (exclusively female) ground that was apparently overlooked at the time that the Directive was drafted. ${ }^{26}$

\section{B. THE REASON FOR ABSENCE FROM THE LABOUR MARKET}

The Court's ruling that the Citizenship Directive does not provide an exhaustive list of the circumstances in which worker status may be retained will no doubt prove useful in the development of arguments supporting claimants who have stopped work for reasons other than those specified in the Directive, but it is the treatment afforded to pregnancy and childbirth per se that is somewhat unsatisfactory. By focussing almost exclusively on the free movement provisions of EU law, the Court avoided the deeper questions relating to the application of the principles of equal treatment and sex discrimination. In doing so, it could have made use of the Charter of Fundamental Rights, ${ }^{27}$ Article 23 of which provides that 'Equality between men and women must be ensured in all areas, including employment, work and pay'. ${ }^{28}$ Such questions were eloquently articulated in the claimant's original submission ${ }^{29}$ which raised a number of issues regarding the application and extent of the equal treatment principle in the free movement provisions. For example, in asserting that the denial of worker status to a female migrant for reasons related to pregnancy and childbirth would amount to direct discrimination without the need for a comparator, ${ }^{30}$ the clamant contested that,

'Pregnancy is not just a lifestyle choice. Equal treatment encompasses the reasonable response of a working woman to the physical demands and limitations of late pregnancy and childbirth'. $^{31}$

\footnotetext{
${ }^{26}$ This omission is explained by Advocate General Wahl in his opinion as arising due to the codification of the case law by the Citizenship Directive which, at the stage that the Directive was drafted, had not considered the circumstances surrounding pregnancy-related absence. See A-G's opinion, paras 27 and 28.

${ }^{27}$ In contrast to Advocate General Wahl's opinion, delivered on 12 December 2013, in which the issue of sex discrimination is considered in some detail and reference is made to Article 21 CFR - see A-G's Opinion, para 35. Article 33(2) CFR which provides for the reconciliation of family and professional life is a carefully-worded codification of the CJEU's case law and refers to everyone having '...the right to protection from dismissal for a reason connected with maternity and the right to paid maternity leave and parental leave following the birth or adoption of a child.

${ }^{28}$ Article 33(2) CFR, which provides for the reconciliation of family and professional life, avoids the possibility that its' aims might be achieved through an individual's withdrawal from market activity and is a carefullyworded codification of the CJEU's case law which refers to everyone having '...the right to protection from dismissal for a reason connected with maternity and the right to paid maternity leave and parental leave following the birth or adoption of a child.'

${ }^{29}$ In which (and in all subsequent hearings) she was ably supported by the intervention of the AIRE Centre.

${ }^{30}$ C 32/93 Webb v EMO Air Cargo [1994] ECR I-03567

${ }^{31}$ Supreme Court judgment, para 19.
} 
Following this line of reasoning, pregnancy and the immediate aftermath of childbirth, as opposed to leaving the workplace to look after children, ${ }^{32}$ should be treated as a special case in decisions surrounding the retention of worker status. This was acknowledged by the Supreme Court's judgment which states, ${ }^{33}$

Only women can become pregnant and bear children. Thus in this respect they cannot be compared to men. Pregnancy is not to be equated with illness or disability. But unless special account is taken of pregnancy and childbirth, women will suffer comparative disadvantage in the workplace. There are also good reasons in health and social policy for allowing women to take a reasonable period of maternity leave without losing the advantages attached to their status as workers. This is different from leaving the workforce in order to look after children. Both men and women may do this and there is no sex discrimination involved in denying them both the status of worker for the time being. We do not see the sex discrimination argument as invalidating Article 7, but as indicating that it would be consistent with the fundamental general principles of EU law for the Court to develop the concept of 'worker' to meet this particular situation.

The Supreme Court's reference to health and social policy echoes the approach taken by EU employment law under which legislative protection surrounding pregnancy finds its legal bases in both the health and safety and equal treatment provisions of the Treaties. ${ }^{34}$ In extending the status of worker to encompass temporary absence due to pregnancy and childbirth the CJEU, by contrast, takes no direct account of the social dimension but relies heavily on an economic rationale. ${ }^{35}$ Equal treatment is considered implicitly but only in relation to a comparison between the treatment afforded to a non-migrant and a migrant in relation to qualification for 'worker' status and not in the context of the direct discrimination arising from the differential treatment received by Jessy Saint Prix compared to that which would have been applied to a sick male migrant under the UK's rules on eligibility for IS.

The long line of pregnancy discrimination cases which form an important part of the CJEU's jurisprudence on equal treatment in employment are referenced only in so far as they prohibit the analogy between sickness and pregnancy ${ }^{36}$ but those cases tell us so much more about the Court's attempts to 'normalise' the effects on paid work of pregnancy so that it is seen as what it is - a natural condition which will nonetheless require some specific temporary adjustments to be made to the woman's usual working arrangements which should not be the cause of unfavourable

\footnotetext{
${ }^{32}$ Case C-325/09 Secretary of State for Work and Pensions v Dias [2010] 1 CMLR 112.

${ }^{33}$ Supreme Court judgment, para 21.

${ }^{34}$ The Pregnant Workers Directive 92/85/EEC found its legal base in 118a EEC and was, thus, an instrument of health and safely law rather than employment protection. Its provisions are expressly referred to in Aricle 2(2) (c) of the Recast Equal Treatment Directive which is has, as its legal base Article 141 EEC (now Art 157 TFEU) which provides 'Discrimination shall include... any less favourable treatment of a woman related to pregnancy or maternity leave within the meaning of Directive 92/85/EEC.' (Directive 2006/54/2006 on the implementation of the principle of equal opportunities and equal treatment of men and women in matters of employment and occupation).

${ }^{35}$ Despite the fact that the Court's previous case law regarding worker status recognises the relevance of factors other than the market value of the individual - see, for example, Case 53/81 Levin v Secretary of State for Justice [1982] ECR 1035; Case 139/85 Kempf v Staatssecretaris van Justitie [1986] ECR 1741; Case 39/86 Lair v Universität Hannover [1988] ECR 3161.

${ }^{36}$ CJEU judgment, para 29.
} 
treatment. ${ }^{37}$ However, even this well-developed area of the CJEU's jurisprudence provides some unsatisfactory outcomes where market inactivity due to the possible effects of pregnancy and childbirth are concerned. In fact, if the free movement rights are compared with the case law relating to employment, an interesting anomaly can be identified by which migrant women who remain in employment are actually placed at a disadvantage to those who do not. Central to the employment case law is the temporal limitation by which the duration of pregnancy and the relevant maternity leave period amount to a 'protected period' beyond which any medical problems which initially arose from pregnancy or childbirth will be subject to the same treatment as ordinary illness. ${ }^{38}$ A straightforward application of the Citizenship Directive to such circumstances reveals that a woman who does experience such health-related problems will be able to rely on the explicit inclusion of a temporary inability to work due to illness in retaining 'worker' status (and therefore access to any relevant benefits) for the purposes of free movement law.

\section{THE RETURN TO WORK}

In his argument before the Supreme Court in the current case, the Secretary of State for Work and Pensions emphasised the 'risk' that women will not return to work after they have had their babies. ${ }^{39}$ This assertion is not evidence-based and in the context of contemporary labour markets within which short-term and zero-hours contracts dominate seems very outdated. The increase in women's economic participation rates, regardless of life stage or family formation, has been accompanied by the advent of labour market flexibility as a key employment policy goal in both the UK and EU contexts. For many women, the result of combining paid work in a flexible labour market with unpaid care for children and other dependents is subjection to high levels of instability, often through part-time and temporary working arrangements which are too often accompanied by low levels of protection and, in the case of zero-hours contracts, the absence of any regular guaranteed earnings. Despite the obvious difficulties experienced by an individual migrant worker in her attempts to sustain a means of supporting herself within such a volatile labour market, the resulting precariousness would, on the face of it, sit well with the 'temporary' breaks envisaged by Article $7(3)$ of the Citizenship Directive.

Those whose reasons for their absence from work accord directly with the provisions of Article 7(3) are not entitled to retain worker status indefinitely and application of the same condition to women who are unable to work due to pregnancy and childbirth actually reflects the reality of many women's experiences. It is commonplace for women workers to leave jobs due to pregnancy and to seek new employment beyond a period of maternity leave. It is interesting that the high levels of mobility in and out of the labour market experienced by so many women during the years of family formation, which might even be seen as desirable by certain employers who are, thus, saved the trouble of having to adapt working practices to accommodate flexible working arrangements or to keep jobs open during the period of maternity leave, can so easily be used against a woman seeking

\footnotetext{
${ }^{37}$ The aim of the protection afforded to pregnancy under EU law has been articulated by the Court as being to achieve "substantive,' rather than formal, equality by reducing de facto inequalities which may arise in society and, ... to prevent or compensate for disadvantages in the professional career of the relevant person' see Case C-104/09 Alvarez v Sesa Start España ETT SA [2010] ECR I-000, para 34.

${ }^{38}$ Case C-394/96 Brown v Rentokil Ltd [1998] ECR I-4185.

${ }^{39}$ Supreme Court, para 17.
} 
to assert her free movement rights. A future practical difficulty will arise in cases where women who find themselves in the same position as the claimant in the current case are unable to secure paid work following a return to the labour market - in such cases it is unclear whether they would be required to pay back any benefits received by virtue of retaining worker status - although it is perhaps these circumstance that the Court had in mind when referring to the need for the relevant national court to consider the 'specific circumstances of the case'. ${ }^{40}$

One particular crumb of comfort relating to the CJEU's handling of the present case lies in its use of Article 45 TFEU as the basis for its judgment, by which it is evident that the established case law dealing with the concept of 'worker' arises through interpretation of primary law. ${ }^{41}$ This disenables the restriction of the concept by secondary legislation and provides some assurance that the judgment is guaranteed. However, by attaching the interpretation of what might be deemed to be 'a reasonable period' to the national rules permitted under Article 8 of the Pregnant Workers Directive ${ }^{42}$ the Court clearly intends to restrict this period to the maternity leave period applicable in the host state. Thus, the question of whether migrant workers will lose their status as workers when they fail to return to work for reasons related to care-giving remains unanswered as the 'reasonable period' clearly would not extend to care-giving beyond the period of maternity leave applicable under national law. Of course, as noted by the Supreme Court, there is no reason why the provision of care should be confined solely to women migrants, ${ }^{43}$ so it would be helpful to see a broadening of the concepts considered in the case to the wider notion of 'parents' at some point. This will, of course depend, on the referral of a case in which the central question relates to the status of unpaid care-giving under the free movement provisions. Given the preoccupation with paid work explicit in the legislative provision and the exclusion of considerations relating to the status of unpaid care under Article 45 TFEU from this area of the Court's jurisprudence to date, it might be some time before the Court is confronted with such a case. ${ }^{44}$

\section{CONCLUSION}

The dissatisfaction expressed thus far with the CJEU's judgment in Saint Prix is not intended to detract from the victory rightly claimed by the claimant and those acting on her behalf. ${ }^{45}$ It is undeniable that the clarification gained by the Court's ruling goes some way in ensuring the protection of pregnant women against discrimination in the exercise of their freedom of movement as EU workers. However, it does seem somewhat incongruous that, more than fifty years after the

\footnotetext{
${ }^{40}$ CJEU judgement, para 42.

${ }^{41}$ CJEU judgment, paras 35-37.

${ }^{42}$ Which provides that workers covered must be entitled to a continuous period of at least 14 weeks of maternity leave allocated either before or after confinement, in accordance with national practice.

${ }^{43}$ See Judgment of the Supreme Court, para 21.

${ }^{44}$ Although see Case C-333/13 Dano v Jobcenter Leipzig, judgment of the Court $11^{\text {th }}$ November 2014, nyr, in which the CJEU held that EU law did not preclude legislation of a Member State under which nationals of other Member States do not have a right of residence under Directive 2004/38 are excluded from entitlement to certain 'special non-contributory cash benefits' despite the fact that such benefits are granted to nationals of the host State who are in the same situation. The case concerned an EU migrant who had never worked in the host state and who was the sole carer of her pre-school aged son.

${ }^{45}$ See Aire Centre Press Release, 19 June 2014, available: http://www.airecentre.org/news.php/140/cjeujudgment-in-saint-prix
} 
free movement of persons was established as a founding principle of the EU and despite the substantial progress made in the recognition of the principle of equal treatment between women and men, in particular in the jurisprudence of the CJEU, pregnancy and childbirth still arise as deviations from 'the norm' to such an extent that they are not expressly provided for as the possible cause of absence from the labour market in the same way as illness or injury. The slow incremental development of the free movement provisions is particularly worrying at a time when the UK, along with other Member States, looks set to further restrict the access of EU migrants to social assistance ${ }^{46}$ thus creating an even more hostile environment than that in which the Saint Prix case arose.

NICOLE BUSBY

The Law School

University of Strathclyde

nicole.busby@strath.ac.uk

\footnotetext{
${ }^{46}$ See David Cameron's recent statements regarding the UK government's intention to renegotiate the free movement provisions of EU law and to restrict EU migrants' access to benefits widely quoted in the press, for example, 'EU migrants in Britain will be stripped of benefits after twelve weeks, available:

http://rt.com/uk/176344-eu-benefits-migrants-cuts/ and 'Tories plan to deny EU migrants out-of-work benefits under universal credit, available: http://www.theguardian.com/society/2014/nov/06/tories-deny-eumigrants-benefits-universal-credit
} 